\title{
EXERCISE EFFECTS ON MUSCLE STEM CELLS
}

\author{
Mihaela JURDANA ${ }^{1}$ \\ ${ }^{1}$ University of Primorska, Faculty of Health Sciences, Izola, Slovenia \\ Corresponding author: \\ Mihaela JURDANA, PhD, \\ University of Primorska, Faculty of Health Sciences Izola, Polje 42, 6310 Izola, Slovenia. \\ Tel.: +38656626469 \\ e-mail: mihaela.jurdana@ffvz.upr.si
}

\section{ABSTRACT}

Satellite cells are skeletal muscle stem cells that facilitate muscle repair and regeneration after "damage" which occurs after physiological stimuli: exercise, post-training micro-injuries and electrical stimulation. Exercise stimuli lead to activation and proliferation of these cells from their quiescent state, therefore, increasing cell numbers having the potential to provide additional myonuclei to their parent muscle fibre or return to a quiescent state. Different exercise modalities are the focus of numerous studies on satellite cells activation. An increase in muscle activity augments satellite cells proliferation as well as skeletal muscle mass and function, both in young and elderly.

This review provides an updated view of the contribution of skeletal muscle satellite cells in regulating skeletal muscle mass and the efficiency of the exercise intervention to attenuate the decline in muscle mass.

Keywords: Satellite cells, acute and chronic exercises, micro damage, muscle regeneration.

\section{UČINEK TELESNE AKTIVNOSTI NA SKLETNO-MIŠIČNE STAMINALNE CELICE}

\section{IZVLE ¿̌EK}

Satelitske celice so skeletno-mišične staminalne celice, ki omogočajo popravilo in regeneracijo mišičnih vlaken po mikropoškodbah, kot je telesna aktivnost, trening ali 
električna stimulacija. Telesna aktivnost sproži prehod satelitskih celic iz stanja mirovanja v aktivacijo in proliferacijo, kar jim omogoča, da se namnožijo in povečajo svoje število. Novonastale satelitske celice se lahko vežejo na matično mišično vlakno ali preidejo v stanje mirovanja. Veliko študij preučuje, kako različne oblike vadbe vplivajo na aktivacijo satelitskih celic ter njihovo število.

Znano je, da mišična aktivnost povečuje proliferacijo satelitskih celic, posledično tudi mišično maso in funkcijo, tako pri mladih kakor tudi pri starejših osebah. Pregled literature $v$ tem članku prikazuje posodobljen pogled na vlogo satelitskih celic pri vzdrževanju mišične mase in pomembnost vloge telesno/gibalne aktivnosti v preventivi pred izgubo le-te.

Ključne besede: Satelitske celice, akutna in kronična vadba, mikro poškodbe, mišična regeneracija

\section{INTRODUCTION}

\section{Skeletal Muscle Regeneration}

Skeletal muscle regeneration is a highly integrated process involving the activation of various cellular and molecular responses; skeletal muscle stem cells play a pivotal role in this process.

Adult skeletal muscle is a stable post-mitotic tissue, small daily injury can be repaired without causing inflammatory responses and cell death. Muscle injury such as extensive physical activity is related to myofibre necrosis, inflammatory responses, and activation, differentiation, and fusion of satellite cells. Muscle regeneration includes the above mentioned processes with a new myofibre formation. Mammalian skeletal muscles consist of different multinucleated myofibers, grouped in slow (type 1) and fast types (2A, 2X, and 2B) with different myosin heavy chain (MyHC) composition. Myofibres also differ in their metabolic profile, extending from slow /oxidative to fast / glycolytic (Schiaffino \& Reggiani, 2011).

The maintenance of skeletal muscle mass depends on mono nucleated muscle precursors or muscle satellite cells. In addition, pericytes, resident in small vessels of skeletal muscle, contribute to its growth and regeneration during postnatal life (Dellavalle et al., 2011). Satellite cells were identified over 50 years ago through electron microscopy by Mauro in 1961 . The satellite cell population varies by age, muscle type, and activity, and are used during muscle regeneration and repair due to their special self-renewal and multi-differentiation capabilities. At birth, satellite cells account for 15 $\%$ of the entire myofibre nuclei population (Thornell, Lindström, Renault, Mouly, \& Butler-Browne, 2003). That proportion latter decreases to between $1 \%$ and $6 \%$ of total myonuclear content in mature muscle fibres (Roth et al., 2000). The major function of satellite cells is contribution to the maintenance of muscle mass, regeneration, and 
hypertrophy by differentiating into myocytes during human's lifespan. Satellite cells are normally non-proliferative, mitotically quiescent and they become activated in response to stimuli such as myotrauma upon injury or muscle growth (Bischoff \& Heintz, 1994), or when skeletal muscle tissue is heavily used during physical activities such as weight lifting or running.

When skeletal muscle is injured, damaged or exercised, satellite cells are activated from their quiescent state, proliferated and fused into existing fibres to provide new myonuclei or return to quiescence (Dhawan \& Rando, 2005). Activation of those cells is not restricted to the site of muscle damage. Satellite cells are activated, migrate and proliferate from different parts of myofibre. However, the number of satellite cells appears to increase in the end part of myofibres, where longitudinal elongation of the skeletal muscle occurs (Yin, Price, \& Rudnicki, 2013).

Importantly, satellite cells have a limited capacity of division entering a state of irreversible growth arrest after a finite number of cell division (Chargé \& Rudnicki, 2004). The self-renewing proliferation of satellite cells maintains the stem cell population and provides abundant myogenic cells which proliferate, differentiate, and fuse to generate new myofibre formation (Yin et al., 2013). With these additional nuclei, muscle fibres can synthesize more proteins and create more contractile myofilaments (actin and myosin) in skeletal muscle cells (Chargé \& Rudnicki, 2004). It is interesting to note that high numbers of satellite cells are found associated to slow-twitch muscle fibres as compared to fast-twitch muscle fibres within the same muscle, as they are regularly going through cell maintenance repair from daily activities (Martin \& Lewis 2012). As satellite cells are constantly replenished during lifetime and are essential for muscle fibre maintenance, a decline in number and reduced proliferative capacity of satellite cells and / or their inability to become activated and proliferate upon stimuli might contribute to muscle fibre atrophy observed in the elderly (Bischoff, 1994; Seale \& Rudnicki, 2000).

Many researchers are interested in new training programs and exercise for developing skeletal muscle mass. However, the mechanism(s) by which exercise induces skeletal muscle hypertrophy remain poorly understood. Through exercise, the muscular work done against progressively challenging overloads leads to increases in muscle mass.

Individual satellite cells respond to exercise and they are influenced by such factors as training status, age, nutrition, and the intensity and volume of the exercise. Duration, frequency and intensity of exercise are important contributing factors in satellite cells activation. Passive stretching of contracted muscles may cause multiple micro damages, disruption of contractile elements or necrosis. For many of us, this happens after changes in the locomotor behaviour by severe onset of exercise. Also after 20 minutes of stepping up and down induces a remarkable increase in muscle-derived proteins in plasma, which reflects some muscle damage (Wernig, 2003). It has been shown that the intensity of the exercise is an important factor in satellite cells activation and muscle regeneration (Martin \& Lewis, 2012). Similarly, other researchers have demonstrated that an increase in satellite cell content depends on the intensity rather than the duration 
of exercise (Bazgir, Fathi, Rezazadeh Valojerdi, Mozdziak, \& Asgari, 2017). Intensive exercise such as resistance training bout induces damage to the muscle fibres, causing activation and proliferation of satellite cells. This biological effort often leads to increasing in muscle fibre cross-section area or hypertrophy (Bischoff, 1994). On the other hand, various muscle groups and types react differently to intensity and volume of exercise.

During muscle hypertrophy, muscle fibre size appears to be related to the size of the myonuclear domain, defined as the amount of cytoplasm within a muscle fibre controlled by single myonuclei (Hall \& Ralston, 1989). Protein synthesis of single myonuclei is confined in myonuclear domain. The amount of cytoplasm controlled by each myonuclei in adult muscle fibre is relatively constant, thus supporting the theory that satellite cells are required for muscle hypertrophy in order to keep the myonuclear domain constant. Considering the presence of other stem cells in skeletal muscle, their contribution in muscle regeneration and hypertrophic growth is possible (Blaauw \& Reggiani, 2014).

\section{METHODS}

Electronic databases MEDLINE, PubMed, and Science Direct including the articles published up to 2017 were used to search literature sources. Different keywords were used: satellite cells (SC), SC during exercise, skeletal muscle regeneration and hypertrophy, SC during ageing. Based on the keywords and review articles, satellite cells activation and proliferation during exercise was described.

\section{RESULTS}

\section{Satellite Cell during Ageing}

It is well known that impairments in satellite cell function during aging result in an impaired muscle fibre regenerative response (Sousa \& Muñoz-Cánoves, 2016; Snijders \& Parise, 2017) leading to the gradual loss of muscle mass and function (sarcopenia) which diminishes muscle recovery after injury in elderly individuals. In many cases this leads to disability and the subsequent loss of independence. A lower number of satellite cell pool and the exhausted proliferative capacity of aged satellite cells may contribute to accelerated loss of skeletal muscle mass during ageing (Renault, Thorne, Eriksson, Butler-Browne, \& Mouly, 2002; Sajko et al., 2004; Joanisse, Nederveen, Snijders, McKay, \& Parise, 2017). Other possible reasons for impaired muscle recovery in elderly individuals relate to the reduced production of growth factors or affect the $\mathrm{e}^{-} \mathrm{c}$ (excitation-contraction) coupling mechanism (muscle-contracting mechanism), (Delbono, O'Rourke, \& Ettinger, 1995). It has also been demonstrated that inadequate muscle fibre vascularization occurring during ageing process 
may be an important cause of impaired regulation of satellite cells in older adults (Snijders \& Parise, 2017).

A certain number of satellite cells seems to be necessary for muscle regeneration during the ageing process. Bengal's recent review (Bengal, Perdiguero, Serrano, \& Muñoz-Cánoves, 2017) has identified the network of cell-intrinsic and cell-extrinsic factors and processes contributing to satellite cells decline during ageing. Most of the studies suggest that the mentioned decline is caused by age-associated extrinsic (environmental changes) and intrinsic mechanisms (DNA damage, oxidative stress). Both mechanisms contribute to muscle stem cell dysfunction. Based on this idea, many studies propose to rejuvenate aged satellite cells to improving muscle repair in the elderly. (Rando \& Chang, 2012; Bengal et al., 2017). Other studies proposed that inadequate activation of Notch signalling, necessary for cell proliferation and cell fate determination, contributes to the loss of regenerative proprieties of aged skeletal muscle (Conboy, Conboy, Smythe, \& Rando, 2003; Bjornson et al., 2012).

\section{Satellite Cells Activation and Proliferation after Exercise}

Resistance and endurance types of exercise training improve muscle mass and strength, and increase the performance capacity in young and elderly. Satellite cells are involved in muscle maturation during postnatal development, regeneration after injury, hypertrophy, hyperplasia and atrophic post-muscle recovery (Dhawan \& Rando, 2005; Chargé \& Rudnicki, 2004). The increase of satellite cell proliferation and activation takes place after short-term muscle activity (Darr \& Schultz, 1987), but the increases in satellite cell numbers only occur after a long term resistance or endurance training (Martin \& Lewis, 2012).

Many studies reported the result of a number of satellite cells following exercise in human (Table 1). Satellite cells get activated from their quiescent state and are involved in muscle regeneration after micro-injuries that follow exercise. Satellite cell content and activity after endurance training can be correlated with time and intensity, duration and frequency of exercise. It has been observed that satellite cell content increased after 30 to 155 minutes of moderate to high-intensity endurance exercises (Parise, McKinnell, \& Rudnicki, 2008; Van de Vyver \& Myburgh, 2012; Bazgir et al., 2017), while no such increase was associated after 30 minutes of low-intensity exercise (Smith, Maxwell, Rodgers, McKee, \& Plyley, 2001). These data confirm the role of the intensity of exercise in satellite cell activation and their role in regeneration and muscle repair.

The acute satellite cell response to exercise has been examined in humans using maximal eccentric contractions of the vastus lateralis muscle by isokinetic dynamometry, as eccentric exercise is considered to induce maximal levels of muscle damage (Gibala, MacDougall, Tarnopolsky, Stauber, \& Elorriaga, 1995). Indeed, it appears that the satellite cell response to acute exercise in humans occurs during the first 24 hours after eccentric exercise, however, there was a significant increase in satellite cells 
Table 1: Summarized studies on human satellite cell numbers following different exercise type (Martin \& Lewis, 2012).

\begin{tabular}{|c|c|c|c|c|}
\hline $\begin{array}{l}\text { Acute/chronic } \\
\text { Training }\end{array}$ & Exercise type & $\begin{array}{l}\text { Muscle } \\
\text { Analysed }\end{array}$ & $\begin{array}{l}\text { Satellite } \\
\text { Cell number }\end{array}$ & References \\
\hline \multirow[t]{6}{*}{$\begin{array}{l}\text { Acute exercise } \\
\text { training }\end{array}$} & RT & VL & increase & $\begin{array}{l}\text { Crameri et al. } \\
2004\end{array}$ \\
\hline & RT & VL & increase & $\begin{array}{l}\text { Dreyer et al. } \\
2006\end{array}$ \\
\hline & RT & VL & increase & $\begin{array}{l}\text { O'Reilly et al. } \\
2008\end{array}$ \\
\hline & RT & VL & increase & $\begin{array}{l}\text { McKay et al. } \\
2009 \\
\end{array}$ \\
\hline & ES & VL & increase & $\begin{array}{l}\text { Mackey et al. } \\
2012\end{array}$ \\
\hline & & & increase & $\begin{array}{l}\text { Mackey et al. } \\
2009\end{array}$ \\
\hline \multirow[t]{11}{*}{ Chronic training } & RT & VL & increase & $\begin{array}{l}\text { Roth et al. } \\
2001\end{array}$ \\
\hline & RT & VL & $\#$ increase & $\begin{array}{l}\text { Petrella et al. } \\
2008\end{array}$ \\
\hline & RT & VL & increase & $\begin{array}{l}\text { Mackey et al. } \\
2010\end{array}$ \\
\hline & RT & VL & increase & $\begin{array}{l}\text { Kadi et al. } \\
2004\end{array}$ \\
\hline & RT & VL & increase & $\begin{array}{l}\text { Mackey et al., } \\
2007\end{array}$ \\
\hline & RT & VL & increase & $\begin{array}{l}\text { Verdijk et al. } \\
2009\end{array}$ \\
\hline & RT & TR & increase & $\begin{array}{l}\text { Kadi and Thor- } \\
\text { nell, } 2000\end{array}$ \\
\hline & RT, ET & EDL, VL & increase & $\begin{array}{l}\text { Verney et al. } \\
2008\end{array}$ \\
\hline & ET & $\mathrm{Pl}$ & * increase & $\begin{array}{l}\text { Kurosaka et al. } \\
2011\end{array}$ \\
\hline & ET & VL & increase & $\begin{array}{l}\text { Charifi et al. } \\
2003\end{array}$ \\
\hline & ET & VL & increase & \begin{tabular}{|l} 
Shefer et al. \\
2010
\end{tabular} \\
\hline
\end{tabular}

Abbreviations:

$\mathrm{RT}=$ Resistance training, $\mathrm{ET}=$ Endurance training, $\mathrm{EDL}=$ Extensor digitorum longus, $\mathrm{ES}=\mathrm{Elec}-$ trical stimulation, $\mathrm{VL}=$ Vastus lateralis, $\mathrm{Pl}=$ Plantaris, $\mathrm{Tr}=$ Trapezius,

* increase of SC number only with high intensity training.

\# increase of SC number only seen in individuals who responded most robustly to RT. 
over pre-exercise values even at later times (O'Reilly et al., 2008). Therefore, satellite cells get activated and proliferated in 24 hours after exercise, and increase considerably between 72 and 96 hours, thereafter they decline in number. (McKay et al., 2009; O'Reilly et al. 2008).

The research data on humans suggest that resistance and endurance training can increase satellite cell content and activation in response to exercise periods from 9 to 16 weeks. (Kadi, Charifi, Denis, \& Lexell, 2004; Petrella, Kim, Mayhew, Cross, \& Bamman, 2008; Shefer, Rauner, Yablonka-Reuveni, \& Benayahu, 2010). However, it should be noted that the resistance type of training leads to an expansion in satellite cell pool with myonuclear addition (Petrella et al., 2008). Muscle fatigue seems to be a stimulus for activation, proliferation and differentiation of satellite cells. Unfortunately, there is little research available that compares satellite cells quantity in response to endurance exercise and resistance exercise. Verney et al. (2008) observed an increase in satellite cell content in the deltoid (resistance-trained) and VL (endurance-trained) muscles after 14 weeks in elderly individuals. Interestingly, a failure in increasing the satellite cell pool after a training intervention was observed in obese, diabetic population (Snijders, Verdijk, Hansen, Dendale, \& van Loon, 2011).

As to animal models, a study on rat soleus muscle showed no increase in satellite cell content after one week of running for 30 minutes per day on treadmill (Smith et al., 2001). While a similar study on mice anterior tibialis muscle reported a significant increase in the satellite cell number and activation (Parise et al., 2008), due to the different composition of muscle fibre type. The study of Smith and Merry (2012) described a six-week resistance type or endurance type of exercise in rats and found no difference between the proportional gains in satellite cell number of the same muscles between groups. These data suggest that endurance and resistance training enhance the satellite cell pool to a similar extent (Marin \& Lewis 2012). In addition, a differential response in fibre-type expansion of satellite cells in response to exercise was observed. Fibre-type classification demonstrates that satellite cells are not equally distributed among the various fibre types and muscles. In human studies, no difference has been detected in satellite cell numbers between fibre types in vastus lateralis untrained muscle of young healthy individuals (Kadi et al., 2006; Verdijk et al., 2007; Snijders et al., 2012), while other studies revealed a greater number of satellite cells in type I fibres and, consequently, minor adaptive potential (Martin \& Lewis, 2012; Bazgir et al., 2017). It was demonstrated that untrained rodent muscle type I fibres contain a greater number of satellite cells in respect to type II fibres. In response to training, the number of satellite cells in type II fibre was increased, while the same increase was not observed in type I (Verdijk et al., 2009; Smith \& Merry, 2012). This process seems sensible as type II fibres give a greater contribution to muscle mass (hypertrophy) and show a higher responsiveness to resistance training (Martin \& Lewis 2012; Bazgir et al., 2017). All these data underline the need of future investigation because the mechanisms of exercise-induced satellite cells activation are not completely understood. 


\section{CONCLUSION}

The maintenance of skeletal muscle mass and regenerative capacity depends on a functional pool of muscle satellite cells. A loss of skeletal muscle satellite cells and defects in their activity are associated with a variety of neuromuscular and other disorders which lead to muscle atrophy.

Exercise training has been successfully applied to augment satellite cells muscle mass and improve muscle function also in elderly. It has been demonstrated that satellite cell activation after exercise together with adequate nutrition are the most effective countermeasures for ageing sarcopenia.

Modalities of exercise, intensity, duration and frequency are correlated with satellite cell content. They are activated and proliferate after acute exercise training, and are increased in number after resistance and endurance training. There are still some discrepancies between the role of volume and the intensity of exercise on satellite cells activation. To clarify the optimal exercise stimuli for satellite cell activation and differentiation, further research is required.

\section{REFERENCES}

Bazgir, B., Fathi, R., Rezazadeh Valojerdi, M., Mozdziak, P., \& Asgari, A. (2017). Satellite cells contribution to exercise mediated muscle hypertrophy and repair. Cell Journal, 18(4), 473-484. doi: 10.22074/cellj.2016.4714 VIEW ITEM

Bengal, E., Perdiguero, E., Serrano, A. L., \& Muñoz-Cánoves, P. (2017). Rejuvenating stem cells to restore muscle regeneration in aging. F1000Research, 6(76). doi: 10.12688/ f1000research.9846.1 VIEW ITEM

Bischoff, R., \& Heintz, C. (1994). Enhancement of skeletal muscle regeneration. Developmental dynamics, 201(1), 41-54. doi: 10.1002/aja.1002010105 VIEW ITEM

Bjornson, C. R. R., Cheung, T. H., Liu, L., Tripathi, P. V., Steeper, K. M. \& Rando, T. A. (2012). Notch signaling is necessary to maintain quiescence in adult muscle stem cells. Stem Cells, 30(2), 232-242. doi: 10.1002/stem.773 VIEW ITEM

Blaauw, B., \& Reggiani, C. (2014). The role of satellite cells in muscle hypertrophy. Journal of Muscle Research and Cell Motility, 35(1), 3-10. doi: 10.1007/s10974-014-9376-y VIEW ITEM

Chargé, S. B., \& Rudnicki, M. A. (2004). Cellular and molecular regulation of muscle regeneration. Physiological reviews, 84(1), 209-238. doi: 10.1152/physrev.00019.2003 VIEW ITEM

Conboy, I. M., Conboy, M. J., Smythe, G. M., \& Rando, T. A. (2003). Notch-mediated restoration of regenerative potential to aged muscle. Science, 302(5650), 1575-1577. doi: 10.1126/science. 1087573 VIEW ITEM

Darr, K. C., \& Schultz, E. (1987). Exercise-induced satellite cell activation in growing and mature skeletal muscle. Journal of Applied Physiology, 63(5), 1816-1821. doi: 10.1152/ jappl.1987.63.5.1816 VIEW ITEM 
Delbono, O., O'Rourke, K. S., \& Ettinger, W. H. (1995). Excitation-calcium release uncoupling in aged single human skeletal muscle fibers. Journal of Membrane Biology, 148(3), 211-222. doi: 10.1007/BF00235039 VIEW ITEM

Dellavalle, A., Maroli, G., Covarello, D., Azzoni, E., Innocenzi, A., Perani, L., et al., (2011). Pericytes resident in postnatal skeletal muscle differentiate into muscle fibres and generate satellite cells. Nature Communications, 2, art.no. 499. doi: 10.1038/ncomms 1508 VIEW ITEM

Dhawan, J., \& Rando, T. A. (2005). Stem cells in postnatal myogenesis: molecular mechanisms of satellite cell quiescence, activation and replenishment. Trends in Cell Biology, 15(12), 666-673. doi: 10.1016/j.tcb.2005.10.007 VIEW ITEM

Gibala, M. J., MacDougall, J. D., Tarnopolsky, M. A., Stauber, W. T., \& Elorriaga, A. (1995). Changes in human skeletal muscle ultrastructure and force production after acute resistance exercise. Journal of Applied Physiology, 78(2), 702-708. doi: 10.1152/ jappl.1995.78.2.702 VIEW ITEM

Hall, Z. W., \& Ralston, E. (1989). Nuclear domains in muscle cells. Cell, 59, 771-772.

Joanisse, S., Nederveen, J. P., Snijders, T., McKay, B. R., \& Parise, G. (2017). Skeletal muscle regeneration, repair and remodelling in aging: the importance of muscle stem cells and vascularization. Gerontology, 63(1), 91-100. doi: 10.1159/000450922 VIEW ITEM

Kadi, F., Charifi, N., Denis, C., \& Lexell, J. (2004). Satellite cells and myonuclei in young and elderly women and men. Muscle \& Nerve, 29(1), 120-127. doi: 10.1002/mus.10510 VIEW ITEM

Kadi. F., Charifi, N., \& Henriksson, J. (2006). The number of satellite cells in slow and fast fibers from human vastus lateralis muscle. Histochemistry and Cell Biology, 126(1), 83-87. doi: 10.1007/s00418-005-0102-0 VIEW ITEM

Martin, N. R. W., \& Lewis, M. P. (2012). Satellite cell activation and number following acute and chronic exercise: A mini review. Cellular and Molecular Exercise Physiology, 1(1), 1-5. doi:10.7457/cmep.v1i1.e3 VIEW ITEM

Mauro, A. (1961). Satellite cell of skeletal muscle fibers. Journal of Biophysical and Biochemical Cytology, 9(2), 493-495. VIEW ITEM

McKay, B. R., De Lisio, M., Johnston, A. P., O'Reilly, C. E., Phillips, S. M., Tarnopolsky, M. A., \& Parise, G. (2009). Association of interleukin-6 signalling with the muscle stem cell response following muscle-lengthening contractions in humans. PLoS One, 4(6), e6027. doi: 10.1371/journal.pone.0006027 VIEW ITEM

O'Reilly, C., McKay, B., Phillips, S., Tarnopolsky, M., \& Parise, G. (2008). Hepatocyte growth factor (HGF) and the satellite cell response following muscle lengthening contractions in humans. Muscle \& Nerve 38(5), 1434-1442. doi: 10.1002/mus.21146 VIEW ITEM

Parise, G., McKinnell, I. W., \& Rudnicki, M. A. (2008). Muscle satellite cell and atypical myogenic progenitor response following exercise. Muscle \& Nerve, 37(5), 611-619. doi: 10.1002/mus.20995 VIEW ITEM

Petrella, J. K., Kim, J. S., Mayhew, D. L., Cross, J. M., \& Bamman, M. M. (2008). Potent myofiber hypertrophy during resistance training in humans is associated with satellite cell-mediated myonuclear addition: A cluster analysis. Journal of Applied Physiology, 104(6), 1736-1742. doi: 10.1152/japplphysiol.01215.2007 VIEW ITEM 
Rando, T. A., \& Chang, H. Y. (2012). Aging, rejuvenation, and epigenetic reprogramming: Resetting the aging clock. Cell, 148(1-2), 46-57. doi: 10.1016/j.cell.2012.01.003 VIEW ITEM

Renault, V., Thorne, L. E., Eriksson, P. O., Butler-Browne, G., \& Mouly, V. (2002). Regenerative potential of human skeletal muscle during aging. Aging Cell, 1(2), 132-139. doi: 10.1046/j.1474-9728.2002.00017.x VIEW ITEM

Roth, S. M., Martel, G. F., Ivey, F. M., Lemmer, J. T, Metter, E. J., Hurley, B. F., \& Rogers, M. A. (2000). Skeletal muscle satellite cell populations in healthy young and older men and women. Anatomical Record, 260(4), 351-358. doi: 10.1002/1097-0185(200012)260:4<350::AID-AR30>3.0.CO;2-6 VIEW ITEM

Sajko, Š., Kubinova, L., Cvetko, E., Kreft, M., Wernig, A., \& Eržen, I. (2004). Frequency of M-cadherin-stained satellite cells declines in human muscles during aging. Journal of Histochemistry \& Cytochemistry, 52(2), 179-185. doi: 10.1177/002215540405200205 VIEW ITEM

Seale, P., \& Rudnicki, M. A. (2000). A new look at the origin, function, and "stem-cell" status of muscle satellite cells. Developmental biology, 218(2), 115-124. doi: 10.1006/ dbio.1999.9565 VIEW ITEM

Shefer, G., Rauner, G., Yablonka-Reuveni, Z., \& Benayahu, D. (2010). Reduced satellite cell numbers and myogenic capacity in aging can be alleviated by endurance exercise. PLoS One, 5(10), e13307. doi: 10.1371/journal.pone.0013307 VIEW ITEM

Sousa-Victor, P., \& Muñoz-Cánoves, P. (2016). Regenerative decline of stem cells in sarcopenia. Molecular aspects of medicine, 50, 109-117. doi: 10.1016/j.mam.2016.02.002 VIEW ITEM

Smith, H. K., Maxwell, L., Rodgers, C. D., McKee, N. H., \& Plyley, M. J. (2001). Exercise-enhanced satellite cell proliferation and new myonuclear accretion in rat skeletal muscle. Journal of Applied Physiology, 90(4), 1407-1414. doi: 10.1152/jappl.2001.90.4.1407 VIEW ITEM

Smith, H. K., \& Merry, T. L. (2012). Voluntary resistance wheel exercise during post-natal growth in rats enhances skeletal muscle satellite cell and myonuclear content at adulthood. Acta physiologica, 204(3), 393-402. doi: 10.1111/j.1748-1716.2011.02350.x VIEW ITEM

Schiaffino, S., \& Reggiani, C. (2011). Fiber types in mammalian skeletal muscles. Physiological reviews, 91(4), 1447-1531. doi: 10.1152/physrev.00031.2010 VIEW ITEM

Snijders, T., \& Parise, G. (2017). Role of muscle stem cells in sarcopenia. Current Opinion in Clinical Nutrition \& Metabolic Care, 20(3), 186-190. doi: 10.1097/ MCO.0000000000000360 VIEW ITEM

Snijders, T., Verdijk, L. B., Beelen, M., McKay, B. R., Parise, G., Kadi, F., \& van Loon, L. J. (2012). A single bout of exercise activates skeletal muscle satellite cells during subsequent overnight recovery. Experimental Physiology, 97(6), 762-773. doi: 10.1113/ expphysiol.2011.063313 VIEW ITEM

Snijders, T., Verdijk, L. B., Hansen, D., Dendale, P., \& van Loon, L. J. (2011). Continuous endurance-type exercise training does not modulate satellite cell content in obese type 2 diabetes patients. Muscle \& Nerve, 43(3), 393-401. doi: 10.1002/mus.21891 VIEW ITEM

Thornell, L. E., Lindström, M., Renault, V., Mouly, V. \& Butler-Browne, G. S. (2003). Satellite cells and training in the elderly. Scandinavian Journal of Medicine \& Science in Sports, 13(1), 48-55. doi: 10.1034/j.1600-0838.2003.20285.x VIEW ITEM 
Van de Vyver, M., \& Myburgh, K. H. (2012). Cytokine and satellite cell responses to muscle damage: interpretation and possible confounding factors in human studies. Journal of Muscle Research and Cell Motility, 33(3-4), 177-185. doi: 10.1007/s10974-0129303-z VIEW ITEM

Verdijk, L. B., Gleeson, B. G., Jonkers, R. A., Meijer, K., Savelberg, H. H., Dendale, P. \& van Loon L. J. (2009). Skeletal muscle hypertrophy following resistance training is accompanied by a fiber type-specific increase in satellite cell content in elderly men. Journals of Gerontology. Series A, Biological Sciences and Medical Sciences, 64A(3), 332-339. doi: 10.1093/gerona/gln050 VIEW ITEM

Verdijk, L. B., Koopman, R., Schaart, G., Meijer, K., Savelberg, H. H. \& van Loon L. J. (2007). Satellite cell content is specifically reduced in type II skeletal muscle fibers in the elderly. American Journal of Physiology Endocrinology and Metabolism, 292(1), E151-E157. doi: 10.1152/ajpendo.00278.2006 VIEW ITEM

Verney, J., Kadi, F., Charifi, N., Féasson, L., Saafi, M. A., Castells, J., et al. (2008). Effects of combined lower body endurance and upper body resistance training on the satellite cell pool in elderly subjects. Muscle \& Nerve, 38(3), 1147-1154. doi: 10.1002/ mus.21054 VIEW ITEM

Wernig, A. (2003). Regeneration capacity of skeletal muscle. Therapeutische Umschau, 60(7), 383-389. doi: 10.1024/0040-5930.60.7.383 VIEW ITEM

Yin, H., Price, F., \& Rudnicki, M. A. (2013). Satellite cells and the muscle stem cell niche. Physiological Reviews, 93(1), 23-67. doi: 10.1152/physrev.00043.2011 VIEW ITEM 